\title{
ARCHAEOLOGICAL SITES AND TOURISM: PROTECTION AND VALORIZATION, CASE OF TIMGAD (BATNA) ALGERIA
}

\author{
Louardi KHERROUR* \\ Houari Boumediene Sciences and Technology University, Department of Geography \\ and Territorial Planning, Algiers, Algeria, e-mail: louardi.kherrour@yahoo.fr \\ Sofiane HATTAB \\ Houari Boumediene Sciences and Technology University, Department of Geography \\ and Territorial Planning, Algiers, Algeria, e-mail: sofianehattab@yahoo.com \\ Mohamed A. REZZAZ \\ Houari Boumediene Sciences and Technology University, Department of Geography \\ and Territorial Planning, Algiers, Algeria, e-mail: drezmas@yahoo.fr
}

Citation: Kherrour, L., Hattab, S. \& Rezzaz, M.A. (2020). ARCHAEOLOGICAL SITES AND
TOURISM: PROTECTION AND VALORIZATION, CASE OF TIMGAD (BATNA) ALGERIA.
GeoJournal of Tourism and Geosites, 28(1), 289-302. https://doi.org/10.30892/gtg.28123-470

Abstract: The archaeological site of Timgad, located in the high plateaus East of Algeria, more precisely in the of Batna province, represents an outstanding universal value, it was classified in the world heritage of UNESCO in 1982, it attracts a significant number of tourists each year and represents an important economic resource. Timgad has benefited from legal and technical instruments of protection and valorization, but these instruments and means have not had the expected success. The objective of this study is to identify this heritage and the tourism reality in this site on the basis of the field study, which has determined the socio-economic characteristics of the visitors and their impressions on the archaeological site and assess the available opportunities. Because the preservation of Timgad which of Roman origin means the protection of heritage, history, art, archeology and science, these potentialities will make tourism an important resource for local and national development. In fact the diagnosis of the current situation confirms the absence of an adequate and coherent tourism planning which allowed us to propose a strategy that combines protection and valorization, while preserving the cultural heritage which is an asset for sustainable development. To accomplish this study, we begun with an analysis of documents and reports concerning the instruments of protection and valorization of archeological heritage. Followed by a field study in form of questionnaires, as well as statistical and geographical data analysis. We finished with a presentation of the results and their interpretation. We finally concluded with some recommendations.

Key words: Archaeological site, Heritage, Tourism, Protection and Valorization, Timgad, Algeria

\footnotetext{
* Corresponding author
} 


\section{INTRODUCTION}

The archaeological site is defined by the International Council of Monuments and sites ICMOSE as a place that gathers traces of a human activity, it is a place laden with history and symbols that express themselves through movable objects or buildings (European Commission, 2004). And Algerian legislation defines it as built or unbuilt spaces which do not have an active function and which testify the actions of man or the actions of man and nature, including the Subsoil which has a historical, archaeological, religious, artistic, scientific, ethnological or anthropological value (Law 98-04, 1998). In this context, it is necessary to define more fully the values of archaeological sites for all mankind, present and future, and to develop processes to manage and present these sites (CSAM, 1995). The Algerian territory is dotted with archaeological sites of an invaluable richness, covering different periods, prehistory, Greek, Phoenician, Roman, Byzantine, Arab and Muslim (Hafsi, 2012; Khouadja, 2016). Where the importance of archaeological sites require cultural, historical, artistic, social and economic values, embodying the history of nations and people and constituting an alive testimony and a highly significant symbol on the genius of human creativity throughout the evolution of the civilizational and human history. Tourists are subjugated by these monuments and sites guided by the desire to discover new environments regions, as well as various civilizations bequeathed by nations and people disappeared ages ago. Antiquities (also remote areas they are) are therefore part of the components of cultural tourism.

Algeria accounts six sites classified World Heritage which are exploited in the cultural tourism: the Kasbah of Algiers, the M'Zab valley, the National park of the Tassili, Qal'a of Beni Hammad, the site of Djemila and the archaeological site of Timgad (Boutemedjet, 2011), which obviously require the protection and valorization. World Heritage has proven to be very popular, it attracted the attention of not only the heritage professionals, but also of tourists, tourism industry and scholars (Tijana, 2007). Algeria has ratified the International Convention for the protection of the urban and natural heritage (Order, 73-38) enacted in 1973, which focused on the need to integrate the objectives of protection and conservation (objectives of development) in order to provide investments in the field of tourism. In this context one of the requirements of the new Algerian political development of the Territory planning (Perspectives 2030) is the protection and enhancement of the cultural heritage, as a factor of sustainable development of the Territory and the registration in the existing policies.

This strategy implements a total and coherent process passing through the inventory, and then the classification, the restoration and finally the valorization. The national strategy for a prospective development and planning of the territory (Perspectives 2030) aims to preserve the national identity and to ensure a territorial and social cohesion through a valorization of cultural heritage (Meradi et al., 2013). The management of the cultural heritage and the promotion of tourism intervene, at the end of this process for the preservation and safeguarding of cultural values. It is possible to enhance the cultural heritage, at the service of tourist activities creators of wealth and employment, which will reconfigure the territory and give it a vocation well precise (Lazzarotti, 2003).

The indices of the World Tourism Organization confirm that cultural tourism will occupy in the next few decades a prominent place in the world tourist offer, thus be susceptible to play a catalytic role in the economies of some countries through the sources of income that they could obtain and provide employment opportunities for the local communities. World Heritage related to research quickly gained momentum in scholarly circles; this resulted in numerous publications in scholarly journals, books and international conferences related to the topic (Tijana, 2007). The relationship between tourism and world heritage emerged recently as a major problem which raises a number of important conferences and work (Laurent et al., 2012). Timgad is an archaeological site classified in the World Heritage of Humanity in 1982 for its Outstanding Universal Value 
became a zone of cultural tourism, it welcomes more than 100,000 visitors per year given its qualifications and available opportunities. However the study area has not yet reached the required level, because of the inefficiency of the adopted instruments of protection and exploitation, and the lack of equipments and tourism infrastructure.

In the light of this, several questions are raised and deserve answers:

1. What are the technical and legal instruments for the protection and valorization?

2. What is the reality of the tourist movement?

3. What are the most effective methods and the tourist projects for the valorization of the archaeological heritage?

\section{STUDY OBJECTIVE AND METHODOLOGY}

The objective of our research is to highlight the outstanding universal value of the studied area, and to show the relationship between the archaeological site and the tourism in the context of the instruments of development (Protection and valorization), and to know the reality of tourism through field study, and to show the importance of the heritage in the development of tourism, and how to make the site more attractive by projects proposed by researchers, as well as to promote the image of Timgad in the national and international tourism markets, to achieve economic, social and cultural benefits, and increase revenues.

To carry out this study, we relied basically on the following steps:

- Field study through 360 questionnaires (elaborated on the basis of direct interview method, have been distributed to tourists) (May 2016). These quantitative and qualitative data are the main constituent elements of the tourism sector and its evolution. In addition to observations and interviews established to know the strengths, weaknesses and opportunities available for the planning and valorization of the site.

- Reports and documents containing laws and instruments, in addition to a few sources and references related to the subject of the study.

- Geographical and statistical data collected using the ArcGIS program

- Results and recommendations.

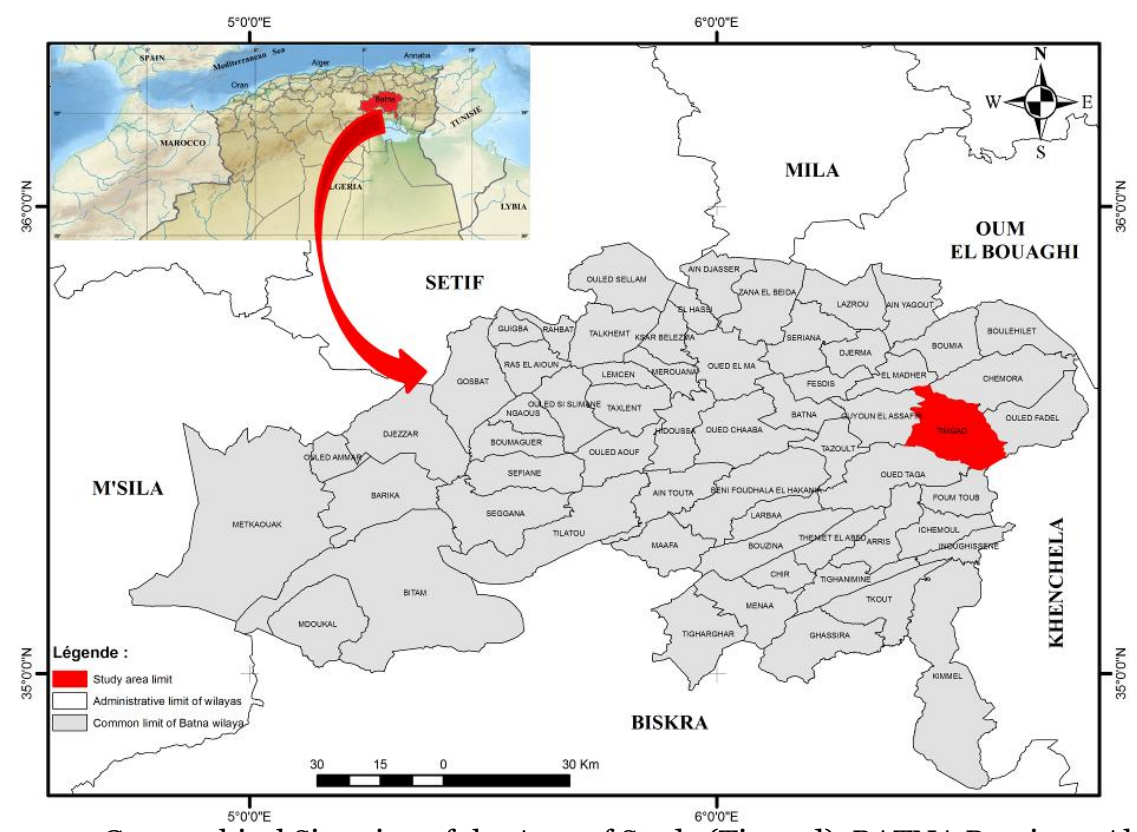

Figure 1. Geographical Situation of the Area of Study (Timgad), BATNA Province, Algeria 


\section{THE STUDY AREA}

The study area (archaeological site of Timgad) dating back to the Roman era, is located in the north-east of Algeria, in a narrow high plain stretching between the northern slope of the Aures massif and Jebel Bouarif, in the territory of the commune of Timgad Batna province (Figure 1). It is located $35 \mathrm{~km}$ at east of the place chief of Batna province, $490 \mathrm{~km}$ to the southeast of Algiers, $110 \mathrm{~km}$ south of Constantine and $68 \mathrm{~km}$ to the west of Khenchela. Bounded by the following geographic coordinates: longitudes: $6^{\circ} 25$ East $6^{\circ} 35$ East and latitudes: $35^{\circ} 27$ North and $35^{\circ} 36$ North, its area is $222.26 \mathrm{~km}^{2}$, located at 900 meters of altitude.

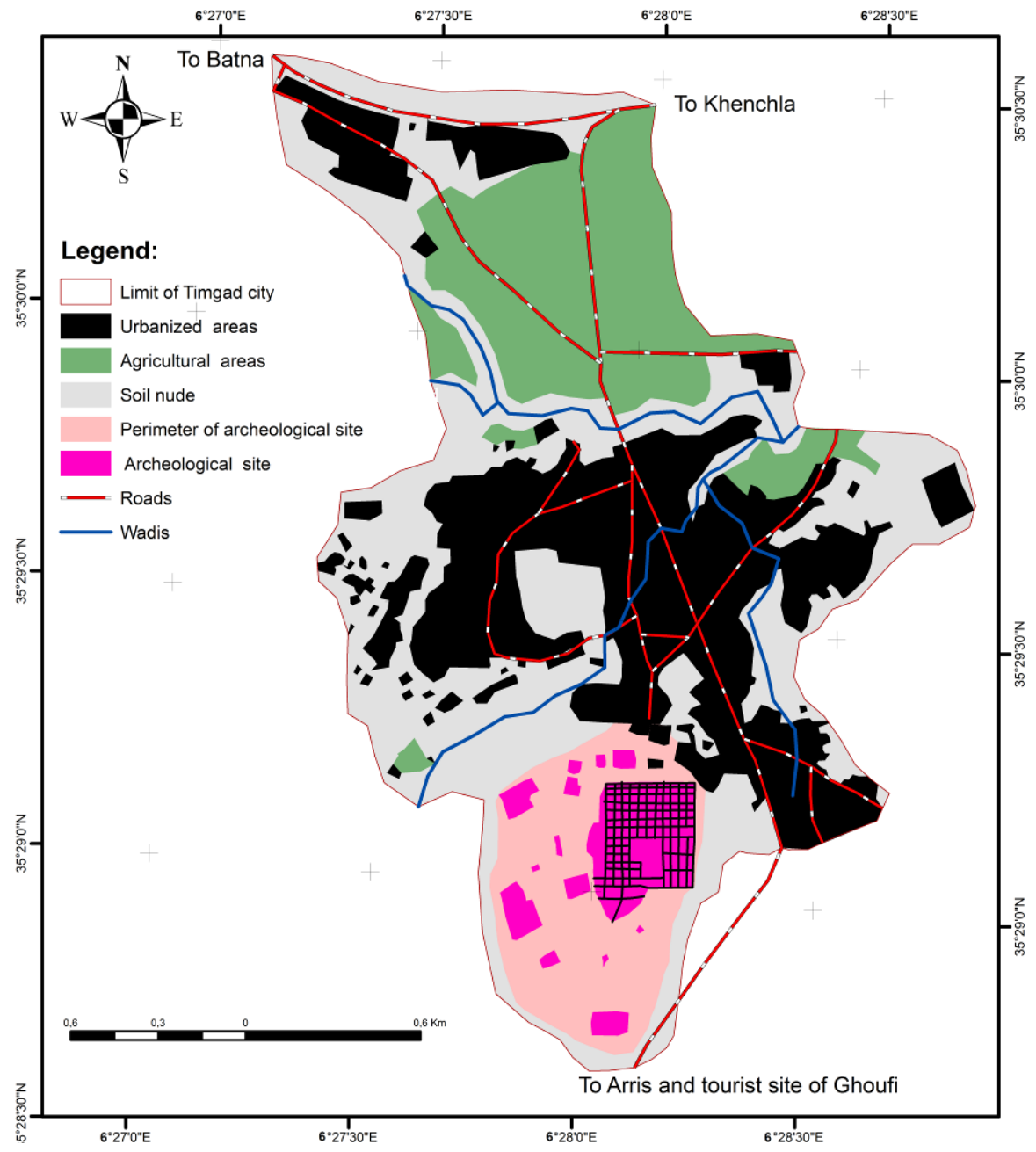

Figure 2. Urbanized Areas and Archaeological Site of Timgad

The study area is characterized by a mild climate throughout the year, with mean annual temperatures ranging up to 28 degrees in July and 10 degrees in December, which gives it a comparative advantage for the following tourist season. Timgad was a colonial Roman city, founded by the Roman emperor Trajan around year 100 after J.C, before it was invaded by the Vandals in the 5th century and then by the Byzantines in the year 535, which have been dismissed by the Berbers in the 7 th century (Monograph Timgad, 2017). 
The Roman city has been covered by a layer of earth up to its excavation in 1881 . From 1948, the need to protect the archaeological site and accommodate the people led to the project of building a new city of Timgad, the design and construction in 1957 of the city to the north of the Roman ruins (Monograph Timgad, 2017). The present city has reached in 2017, 15000 inhabitants. The archaeological site in the north side is threatened by the urban fabric (Figure 2). The distance that separates the site from the urban area does not correspond to national and international standards that estimate between 200 and 500 meters. The physical limits of the site extend to surrounding areas, so that the area of separation between the archaeological site and the urban area should be defined. Because, according to the standards of urban planning, the perimeter of the site of Timgad is a "non-Sector urban sable", where any construction or other use of soils is strictly prohibited. The modern city was created in 1957, to be built at $1000 \mathrm{~m}$ to the north of the ruins of the Roman city, the extension of the city is close gradually.

\section{PROTECTION AND REVALORIZATION INSTRUMENTS}

The United Nations UNESCO has adopted a number of international principles with regard to the archaeological excavations indicating the criteria to use to develop the archaeological sites (Samuel et al., 2014). Heritage sites should be managed effectively in a way that ensures preservation of heritage resources and their presentation to the public (Alazaizeh, 2014). In Algeria the (Law 98-04, 1998) related to the national cultural heritage, is the main reference in the field of protection, followed by a series of regulatory texts, which has led to the change of concepts, standards and controls relating the protection, procedures of classification, general provisions, standards relative to the restoration. It is certain that this innovative approach, need to be reinforced and supported concerning the implementation of plans for the protection and enhancement of archaeological sites (SNAT, 2010).

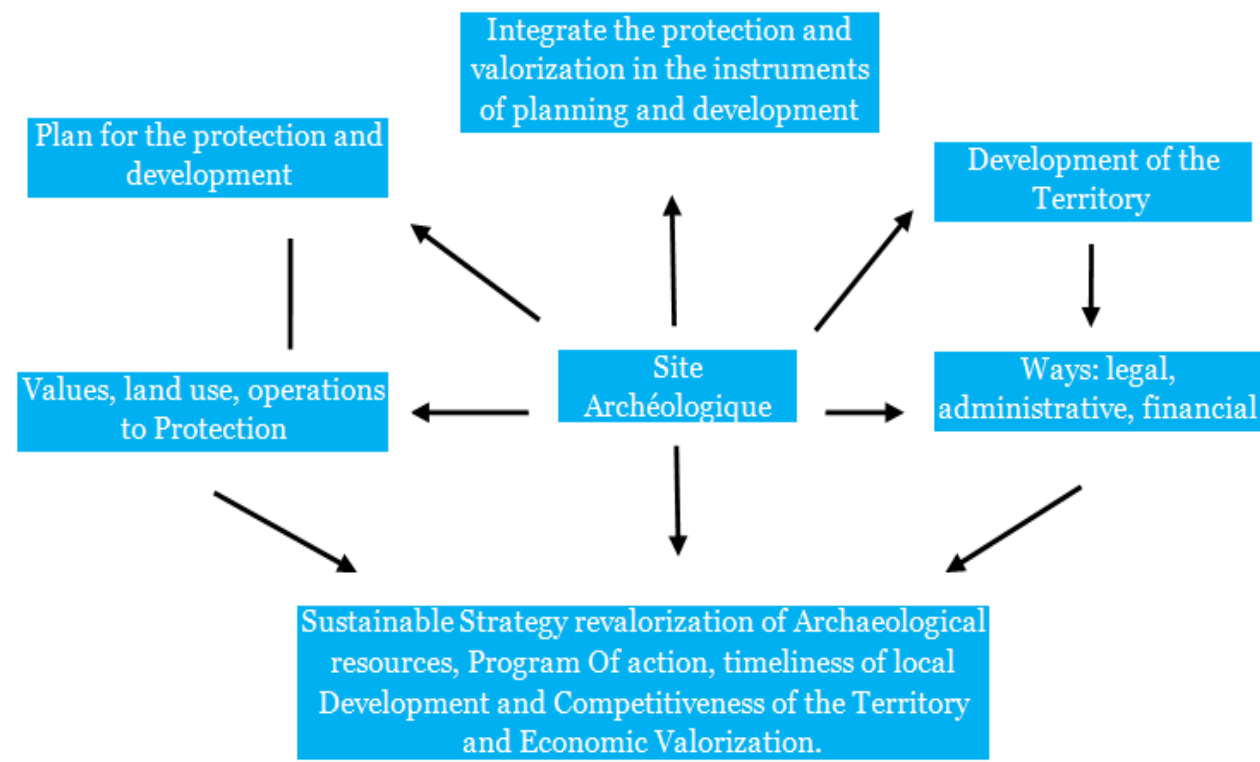

Figure 3. Archaeological Site of Timgad and instruments for planning and Territory development

We note that the elements of the archaeological heritage of Timgad are taken into consideration by the procedures organized in the field of Urban and Territorial 
planning at several levels (Figure 3), national scheme for Territory planning (SNAT). Scheme of Space of territorial programming of the East High plateaus (SEPT), the Land Use Plan Batna province (PAW) and the Master Plan for Development and Planning of the commune of Timgad (PDAU). All development plans incorporate the valorization of heritage and tourism potential, for example the National Scheme of Territory planning (SNAT) proposes the creation of an economic pole of heritage around the archaeological site of Timgad. This strategy aims to build a project in consistency with the local identity and create an active cultural environment. On the operational plan, Timgad is regulated by a plan of protection and Development (PPMVSA), it is a legal and technical instrument which determines all the actions for the conservation and management.

The plan highlights the current state of archaeological values for which is established the PPMVSA, and lays down the general rules for the use of land and easements as well as the operations envisaged in the framework of the protection, management, operation and enhancement of the site, including those relating to the determination of the activities that can be performed within the limits of the Classified site and its Protection Zone (Executive decree 03-323, 2003). This intervention method is directed towards a Social, economic, cultural and touristic development as a tool for local sustainable development. Therefore, the strategy for the protection of heritage areas often requires the form and measures of plans and methods of restoration, conservation, rehabilitation, leading to an exemplary conduct in respect of heritage sites. It is then essential to better understand the mechanisms of the economic spinoffs, their impacts at the local level and to demonstrate that the development of the heritage is not only a burden but an asset that can generate profits in the tourism sector (UNESCO, 2013).

Algeria is seeking since long time ago to achieve development objectives and to promote the tourism sector using various planning and development instruments (Benzarour et al., 2016). Tourism planning is able to promote the development of archaeological and heritage sites in order to qualify them for tourist attraction and the implementation of sustainable tourism development projects resulting from economic, social and cultural interests and benefits, at the national and local levels (Kabachi, 2010). Nowadays, tourism is a completely different concept comparing past times and its economical background is exceeding day by day (Bagherzadeh et al., 2016).

In the framework of the national policy for the development of tourism and the development of the Territory, the commune of Timgad has benefited from an area of expansion and tourist site (ZEST) in 2010 on an area of 852 hectares for the development of tourist infrastructure (Executive decree 10-131, 2010). Located in the south of the urban area said Morri, outside of the limits of the archaeological area in the west of the site (Figure 4), the area is classified as lands belonging to the State, with a topography almost perfectly flattened. It also has a potential of infrastructures and water, sanitation, electricity and gas networks. In this context, the study area has benefited from a plan of touristic development PAT (Currently under study), the plan must include natural, social, economic, cultural and environmental aspects in the data, indicators and standards, (Executive decree 07-86, 2007) as well as the overall approach to the touristic attractions planning and variables of development (variables and hypothesis) for the development of projects and appropriate activities.

The steps of Tourism Development planning process:

- Diagnosis and potential for tourism;

- Analysis, evaluation of the variables and strategies of development;

- Strategy chosen, prospects for planning and tourism development;

- Regulation of land use;

- Implementation program. 
The plan proposes the creation of a touristic village of 73 hectares (PAT, 2015), providing for short-term: structures of accommodation and a range of hotels and of cultural and sports facilities, leisure parks, public gardens, green spaces, equipment, services, equestrian area, and other projects, complying with the national and international standards in the context of the local specificities. For the implementation and monitoring of touristic and development plan (PAT) on the ground, steps have been taken to the creation of the National Agency of Development of Tourism in charge of ensuring the protection and preservation of the touristic extension zones, and to conduct studies, development, and acquisition of the land required for the implementation of touristic infrastructures (Executive decree 98-70, 1998). The State undertakes the development of works leading to the preparation and completion of the studies, the private sector performs the different projects (Structures and Equipment), within the framework of laws and regulations.

The study area has benefited from certain development programs, in the framework of the instruments for Territory development:

- Pole of economic heritage (PEP), which constitutes a form of revalorization of archaeological resources;

- Plan for the protection and enhancement of archaeological sites and their zone of protection (PPMVSA), legal and technical instrument which determines all the actions of conservation and management;

- Area of expansion and tourist site (ZEST);

- Plan of tourism development (PTD), for the achievement of tourism infrastructure.

The protection of the archaeological heritage is among the objectives of the instruments of development and Territory planning for a better integration and reconciliation of the requirements of the protection and tourism development. Despite its tools and instruments, no intervention has been carried out on the study area. The touristic pole center located near the picturesque areas (mountains, forests, water plans), is also close to other touristic sites, such as the Ghouffi, Tazoult, medracen, Chelia, and others (Figure 4).

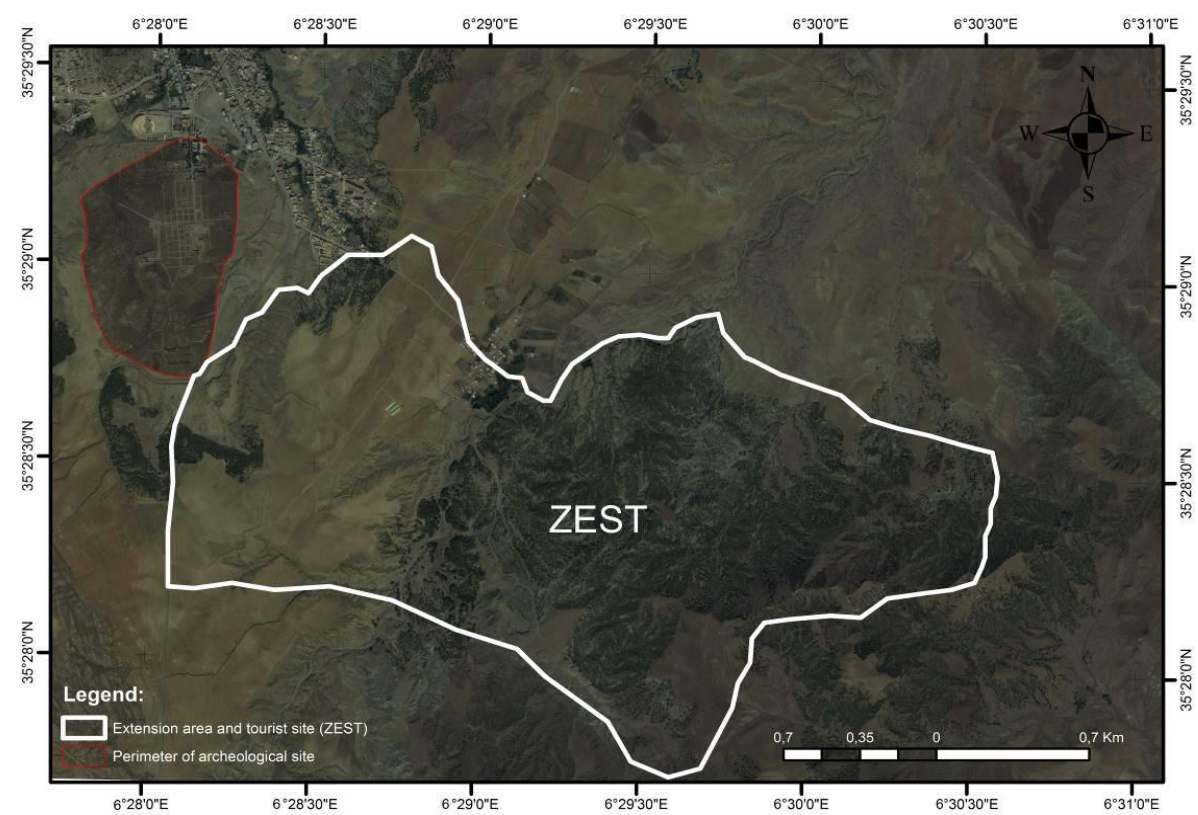

Figure 4. Touristic Project located outside the Protected Area 


\section{FROM HERITAGE TO TOURISM}

Timgad is considered one of the most important archaeological sites in Algeria, it was baptized by the Romans by the name of Thamugadi around the year 100 after J. C, where it flourished until the fifth century AD. Timgad was initially predestined for military strategic purposes, but subsequently transformed into a residential area, and constructed according to an orthogonal design (checkerboard plane), around two main and perpendicular axes (the Cardo and The Decumanus), it represents a unique and distinctive model of construction type and organized planning. It was incorporated into the World Heritage of mankind List in 1982 (SDZAH, 2007).

Timgad takes up the precepts of the planned urban planning of the Roman period, governed by a remarkable orthogonal checkerboard plan, thus constitutes a typical case of an urban model (Sebahi, 2016). It is a unique and singular work; it embodies an important model of construction type and regular planning. The monuments of the site are: The Forum, the theatre, the library, the Capitol, the Arch of Trajan, the thermal baths, the individual habitat and others. The presence of Timgad in the picturesque region of Aures has given it great cultural and natural touristic specificity. Heritage creates a high degree of multiplicity of natural and cultural heritage that may play an important role as a possible motor for truly sustainable development from the standpoint of geo- and cultural tourism more in general (DI Gregorio et al., 2014).

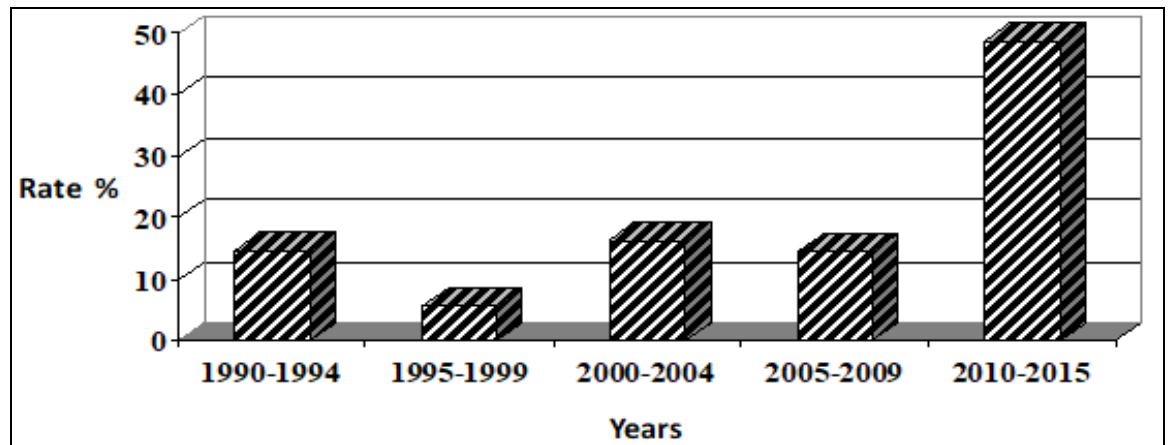

Figure 5. Evolution of Visitors number on the Archaeological Site Timgad, 1990-2015

According to Figure 5; (Timgad Archaeological Department, 2016) we notice that the number of tourist arrivals who visited the archaeological site of Timgad, during the period (1990-2015) reached 1132880 tourists (domestic and foreign). The period 20102015 occupies the first position with 49\%, where tourism has an upward trend in continuous growth, due to the stability of the security as well as the promotion of tourism in the region. The number of foreign visitors is very low compared to the number of Algerian visitors reaching 1780 in 2015 (DTA, 2015). While the period 1995-1999 was relegated to the last row with a rate of $5.64 \%$, due to the security events experienced by Algeria during this period, which diminished number of tourists in the direction of Algeria and Timgad in particular. Tourism in the study area is characterized by two seasons: the first in spring (March-April-May) with 50\% and the second during the summer months (June-July-August) with $25 \%$ of the total number of tourists (Figure 6). This is obviously due to the good climatic conditions enjoyed by the study area during these two seasons, the ideal atmosphere having an appropriate positive impact on the tourist attendance rate. The Timgad International Festival is one of the most important tourist and media attractions in the region in July of each year. During the 10 days of the festival, the attendance recorded in the Roman city was of 15230 tourists (Kherrour et al., 2016). The 
Ministry of Culture has transferred the activities of the annual Festival of Timgad to the outside of the site, which will mitigate the negative impacts on the area (Sebahi, 2016).

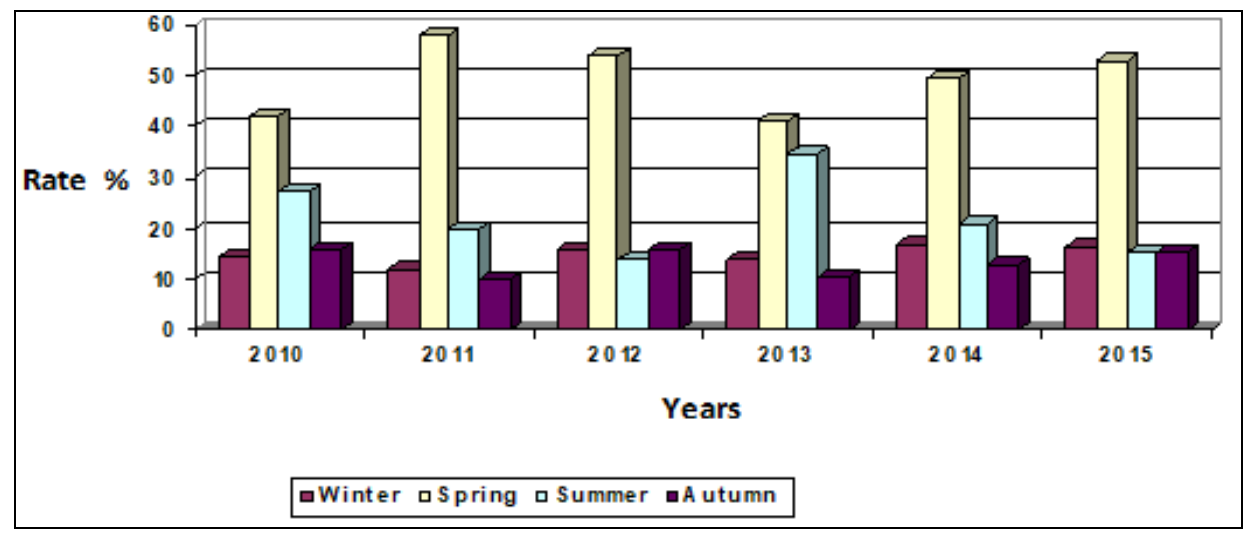

Figure 6. The relative distribution of the Touristic movement seasonality, Timgad 2010-2015

We notice that the touristic movement is still very modest for the rest of the year, the general trend is very significant in terms of the marked and noticed tourist traffic during the spring and summer and culminating at the rate of $75 \%$, as we underline a significant increase in the tourist flow during the official holidays and the annual events. Heritage tourism has become one of the main tools to maintain heritage sites (Alazaizeh, 2014).

\section{RESULTS AND INTERPRETATIONS}

After the analysis of the touristic movement in terms of the evolution between 1990 and 2015, and the number of tourists according to the seasonality (2010-2015), we will highlight the tourism reality through the social and economic characteristics of tourists, as well as the General impressions on the archaeological site to that end. 360 questionnaires have been distributed to tourists (May 2016).

The main results of the questionnaire are:

\section{Age category and Place of accommodation}

The reading of the Table 1 allows us to say that the most represented age category is between 21 and 40 years with 69\%, which corresponds to the young seniors, followed by that of $41-60$ years with $14 \%$, then by the category of less than 20 years with $13 \%$, indicating that this category moves in group (students). And according to the inquiry the tourists originating in the Batna province represent $67 \%$. The tourists stay duration: $79 \%$ which do not exceed a day, $15 \%$ up to 3 days and $6 \%$ for a week, but for most of the tourists the duration of the stay does not exceed 24 hours, they are traveling in the region especially during weekends. There is a fairly significant percentage of tourists $44 \%$ which do not specify their place of stay and who come to spend a few days in Batna province, and concerning the percentage of accommodation in hotels it hardly exceeds $11 \%$, where we note only the existence of two hotels: the Hotel El Kahina with 44 beds (Not classified) and the hotel of the Ruins with 60 beds (Under the renovation and rehabilitation). Therefore we note a significant Inadequacy, in particular with the existing hotel facilities in terms of quantity and quality, to meet touristic standards at international levels. The number of rooms identified in the hotels is evaluated to 84 rooms only, which requires an increase in the capacity of accommodation in order that the dynamics and the development of tourism pouring in the city can be absorbed in order to achieve the balance of supply and demand in tourism. We note that the youth hostel with a capacity of 
40 beds plays a preponderant role in the movement of the internal tourism where the universities and the different institutions prefer to organize trips in the region and stay in the youth hostel; which actually represents a significant portion of the city tourism capacity.

Table 1. Indicators on the Tourist Movement in the Archaeological site of Timgad

(Source: survey accomplished by the students of urban planning (license degree FSTGAT, May 2016)

\begin{tabular}{|c|c|c|c|}
\hline Indicators & Alternative & $\begin{array}{l}\text { Number of } \\
\text { Interviewed }\end{array}$ & $\%$ \\
\hline \multirow[t]{2}{*}{ Sex } & Man & 233 & 64 \\
\hline & Woman & 127 & 36 \\
\hline \multirow[t]{2}{*}{ Marital status (family) } & Married & 141 & 39 \\
\hline & Single & 219 & 61 \\
\hline \multirow[t]{4}{*}{ Age } & Age under 20 years & 50 & 13.8 \\
\hline & Between 21 years and 40 years & 250 & 69.4 \\
\hline & Between 41 years and 60 years & 51 & 14.3 \\
\hline & Over 61 years & 9 & 2.5 \\
\hline \multirow[t]{5}{*}{ Education Level } & Primary & 24 & 6.6 \\
\hline & Middle cycle & 83 & 23 \\
\hline & Secondary & 109 & 30 \\
\hline & University & 122 & 34 \\
\hline & Higher & 22 & 6.4 \\
\hline \multirow{2}{*}{$\begin{array}{l}\text { Place of residence according } \\
\text { to the Provinces }\end{array}$} & Batna province & 241 & 67 \\
\hline & Outside the Batna province & 119 & 33 \\
\hline \multirow[t]{3}{*}{ Stay duration } & One day & 284 & 79 \\
\hline & Between 1 and 3 days & 54 & 15 \\
\hline & More than a week & 22 & 6 \\
\hline \multirow[t]{4}{*}{ Place of accommodation } & Hotel & 37 & 10.2 \\
\hline & Flats & 142 & 39.4 \\
\hline & Cottage & 21 & 6 \\
\hline & Other & 160 & 44.5 \\
\hline \multirow[t]{2}{*}{ Attractiveness } & Yes & 338 & 94 \\
\hline & No & 22 & 6 \\
\hline \multirow{4}{*}{$\begin{array}{l}\text { Motives of the touristic } \\
\text { movement }\end{array}$} & Archaeological site & 172 & 48 \\
\hline & Rest and leisure & 90 & 25 \\
\hline & Scientific tourism & 62 & 17 \\
\hline & Cultural Festival & 36 & 10 \\
\hline
\end{tabular}

\section{Motives of the tourist movement}

The site of Timgad is the factor of an essential touristic attraction at the region level with $48 \%$ of tourists (the Survey 2016), however, the rest and relaxation are most important, estimated at $25 \%$, as well as the scientific tourism with $17 \%$. Most people interested by the rest and relaxation, as well as ecotourism (natural areas, mountain and aquatic basins) are residents of neighboring municipalities. The dam of Koudiet Lamdaouar, located in the north of the city, at $7 \mathrm{~km}$ constitutes an economic and touristic resource to the local and regional level and which has given the area an environmental character, making the region a destination highly appreciated by the local tourists residents on the territory of Batna province. The Mont Bouarif, which is located in the north of the municipality to a height of $1745 \mathrm{~m}$, is an area of excellence dedicated to mountain and environment tourism which encourages the establishment of structures and touristic facilities.

\section{General Impressions}

The knowledge of the tourists wishes and their satisfaction is related to the beauty of the site, the cleanliness of the environment, services, expenditures, security, stability, recreational activities, etc. This information helps to develop plans and strategies for the 
development of tourism. According to the data of the questionnaire (2016), the beauty of the site is the first element of tourists satisfaction, 94\% have expressed their desire to return soon, and recommend to their relatives or friends to visit the site in the future. Most of the negative impressions of the tourists and visitors to the archaeological site are mainly related to the lack of various activities and services.

\section{Attractiveness of the Territory}

The development of new services will generate new employment opportunities and will increase the opportunities for the improvement of local revenues. For example, a tourist in the archaeological site, buys a ticket of entry, uses a guide, buys local products (purchases, restaurants, transport, accommodation, and other touristic activities). These expenses are an important and effective factor for the local economy in addition to the traditional crafts which constitutes one of the elements of intangible heritage in the region, mainly in the traditional clothing, pottery, the engraving and jewelry (gold and silver), given that the region is rich in its distinctive folklore, thanks to the diversity of the cultural resources and the different civilizations of the Aurès. The local heritage contributes to the promotion of tourism and ensures the attractiveness of the Territory (Julie, 2013).

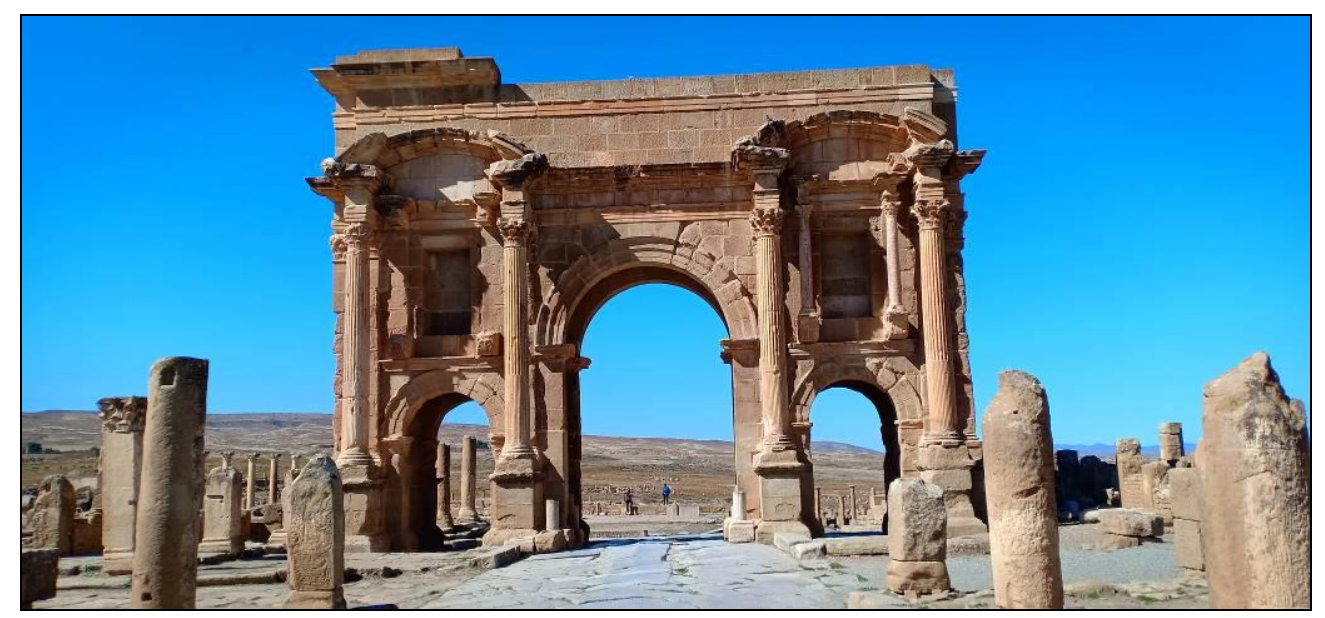

Figure 7. Arch of Trajan

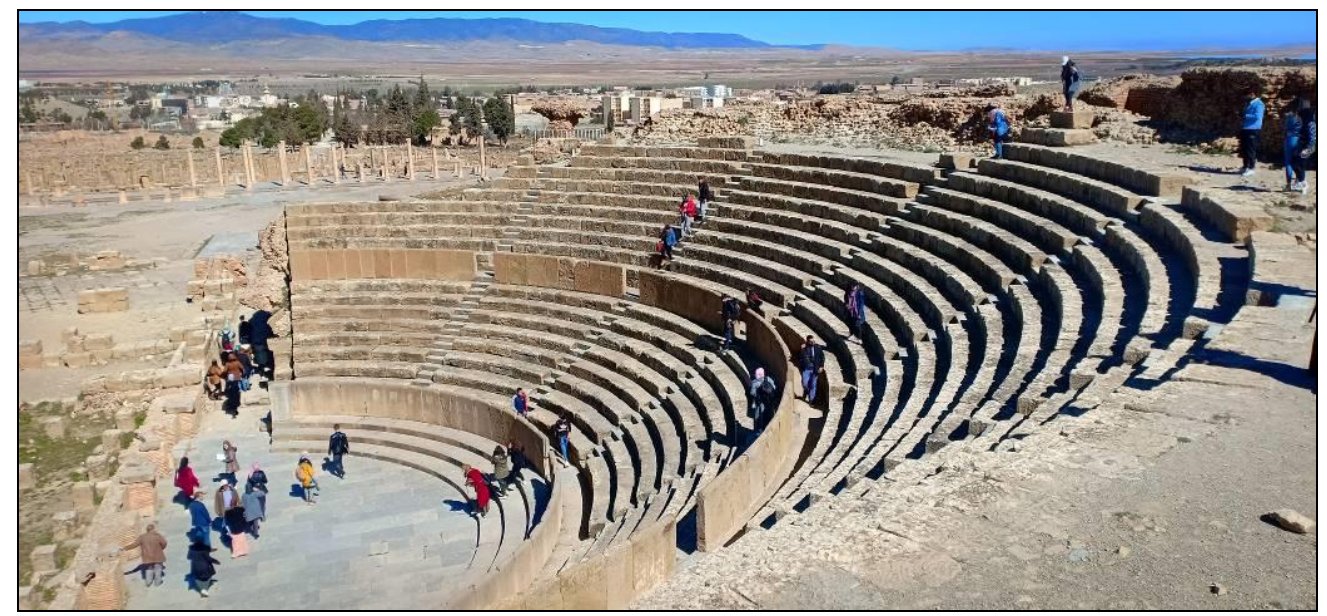

Figure 8. Theater 
The relationship between the archaeological heritage and tourism is dynamic, so that the site must be maintained in a sustainable way for present and future generations. The cultural heritage (figure 7,8 ), and the International Festival of Timgad are among the most important touristic attractions of the region. The economic benefits that heritage sites bring to the tourism destination are through the increasing of visitation and the extensions of stay ( $\mathrm{Du}$ Cros, 2008). The cultural heritage is regarded as an important sector of the regional and local economy and a key factor of development. The cultural tourism is today a major factor in the economies of some countries and recent studies indicate that the proportion of cultural tourism worldwide is situated between 12 and 15\% of tourism in general and sometimes even $20 \%$ in the areas richest in heritage. It is clear from the foregoing aspects that the number of visitors to the study area has experienced a rising trend, and most of the impressions of the tourists and visitors to the site are mainly related to the lack of services and activities. And the lack of hotel establishments responding to the touristic standards of high level is limited to the existence of two non classified Hotels. The cultural tourism is not developed because of the negligence of modern methods to administer and manage the site, and the failure of the media to advertise in order to attract tourists. The commune of Timgad needs a plan for touristic development adapted to the nature of the region, in order to assess and develop tourism. However Timgad has an area of tourist expansion in conformity with the executive decree 10-131 of 2010, which is an important factor for the development of tourism as well as the attraction of foreign and domestic investments that can have a positive impact on the region.

\section{CONCLUSION AND RECOMMENDATIONS}

This study focused on the theme of archaeological site and Tourism (Protection and valorization), taking as a case study Timgad. The results of the research show that the State has integrated the protection and enhancement of the archaeological site in the instruments of development and sustainable development of the Territory, through a series of legislative and regulatory texts and various instruments, but the impact of the strategy toward the heritage and tourism, required several actions and means (legal, administrative, technical, financial, and public-private partnership), which has led to the failure of the application of the instruments on the ground. This is confirmed by the results of the 2016 investigation, no intervention has been carried out on the site in the framework of the protection in addition to the lack of equipment and tourist infrastructure in the commune of Timgad. Through the results of the study, we have suggested a series of recommendations aiming to:

- Preserve the site which is a key factor of tourism attraction through the restoration of monuments, and the stoppage of urban extension towards the archaeological site.

- Develop an operational plan for the protection and valorization of the site, this protection will only be sustainable if the archaeological sites are valued as economic resources that attract investment, this valorization must be included in Territory development programs (Hafsi, 2012).

- The strategy of protection and revalorization requires the development of tourism investment and the creation of structures of accommodation, services and leisure. The East area of the site is particularly adapted to the expansion of the proposed projects, because the standards of protection require a natural space between the site and the tourism projects, to move away from the protected area, in order to demonstrate the vision of the archaeological monument and provide a natural environment.

- Each new construction must comply with the standards of protection in terms of types, height, forms, facades, construction materials, colors, use and compatibility with the local and archaeological environment. 
- Realize investments with touristic vocation adapted to the nature of the region (structures of accommodation and services), and develop the international tourism by establishing hotels to host the expected growth in the number of tourist, given that heritage is an important part of the international tourism market (Mohinder, 2013).

- Establish a cultural center and a museum of heritage to stimulate cultural and scientific events, and the insertion of the heritage in the development, because museums today play an important role at the global level and are more active due to the application of modern techniques applied in the museum exhibitions. For example, tourism represents for France a very important economic sector, World Heritage sites as Versailles with 6 million visitors per year, or the Museum of the Louvre with 9 million visitors per year (UNESCO, 2013).

- Develop the Craft industries, organize festive events that reflect the aspects of local life and captivate the admiration of tourists.

- Develop a plan for information by using modern tools to promote the tourist attractions, cultural events, festivals, exhibitions and scientific seminars, and to put in value its assets as well as to capture the investment opportunities.

- Raise the level of awareness of the population from the region regarding the importance of the cultural heritage and its role in the economic and social development. For the realization of touristic projects, it is necessary to carry out preliminary impact studies which include an analysis of the archaeological heritage and its environment and makes it possible to conceive the project of development according inheritance protection rules.

- Touristic projects become a key element of development and an important source of income that is beneficial to the commune and its residents, thus contributing to the improvement of their standard of living and the creation of direct and indirect jobs, which therefore makes the development based on the tourist activity a tool for the stimulation of other sectors such as urbanization, construction, transportation, trade, agriculture, and various services.

Through the recommendations we aim to:

- Strenghten the attractiveness of the region;

- Develop a sector of cultural economy (heritage);

- Create tourism development from the archaeological site.

These projects will become a source of income, employment and development, in the commune of Timgad, which suffers from a lack of resources and income. Timgad, this archaeological site of an international, historical, cultural and civilization value, requires exceptional measures, for a new culture of sustainable development. It should be protected, rehabilitated and landscaped to keep its authenticity and guarantee the competitiveness and sustainability of the heritage, in order to reach a sustainable model in which the heritage plays a dominant role and is a tourist resource of the first order.

\section{REFERENCES}

Alazaizeh, M, M. (2014). Sustainable Heritage Tourism: A tourist-Oriented approach for managing Petra Archaeological Park, Jordan, Doctor of Philosophy Parks, Recreation and Tourism Management, Clemson University, États-Unis, P1.

Alazaizeh, M.M, Jeffrey, C. Hallo, Sheila \& Backman. J. (2018). Giving, voice to Heritage Tourists: Indicators of quality for a sustainable Heritage Experience at Petra, Jordan, Journal of Tourism and Cultural Change, Mar 2018.

Bagherzadeh .A \& Keshavarz. A. ( 2016). Analyzing the effective factors on tourism demand in elgoli jungle park of tabriz city, iran, GeoJournal of Tourism and Geosites Year IX, no. 1, vol. 17, P 64.

Benzarour, C, \& Satour, R. (2016). Tourism and Economic growth in Algeria: Evidence of Cointegration and Aalgiers causal University 3, Blida University 2, Algeria, P11. 
Boutemedjet, S. (2011). Policies for the Conservation of the Archaeological Heritage, the Case of the Archaeological Site of Madaure, wilaya of Souk Ahras, Memory of Magister, Faculty of Earth Sciences, University of Annaba, Algeria, P22.

DI Gregorio, F, Frongia, P, Piras, G, \& Forresu, R. (2014). Map of the Natural and Cultural Heritage in the landscape of the carignano wine district of the sulcis region (sw sardinia), GeoJournal of Tourism and Geosites, Year VII, no 1, vol 13, P 66

Du Cros, H. (2008). Too much of a good things, Visitor congestion management issues for popular world heritage tourist attractions. Journal of Heritage Tourism, 2(3), P 225-238.

Hafsi, F, Z. (2012). For an integrated conservation of archaeological sites in the national policy for Territory planning, example of study: Souk Ahras province, memory: magister (Master degree), Faculty of earth Sciences, geography and Territory planning, Universite MENTOURI, Algeria.

Julie, A, (2013). Archaeological Heritage, Tourism and attractiveness of territories.

Kabachi, H.K, (2010). Tourism Planning and its impact on the areas and sites of Archaeological Heritage, Review of the University of Shendi, Sudan, N 9, P127.

Kherrour, L., Souiher, N., \& Drias, A. (2016). Toward a setting in Eco-cultural tourism development in the area of the Ghoufi Batna province, Algeria, Review Geographia Napocensis, Anul 1. P13.

Khouadja, S, H, (2016). The protection of archaeological property through the law of cultural heritage, review Cahiers of Politics and Law, Kasdi Merbah Ouargla University, Algeria, No. 15, P 71.

Laurent, B, Maria Gravari-Barbas, \& Robinson, M. (2012). Tourism and world heritage, 'Laval University. Canada, 2012, P17.

Lazzarotti, O, (2003). Tourism and heritage, Annals of geography, Volume 112, No. 629. P91-110.

Meradi,O, Belattaf, M \& Albagli,C. (2013). National Scheme for Territory planning and cultural changes in Algeria, Euro-Mediterranean Dialog of Public Management, MED 6, 7, 8 \& 9 October, 2013, Marseille, France. P9.

Mohinder, C, (2013). Residents perceived benefits of heritage and support for tourism development in Pragpur, India, Journal of Tourism, Vol 61 / No 4, P 379.

Samuel J, \& Fernandoe, Soberanis. (2014) Alternative Tourism and Archaeological Sites in Yucatan, Mexico, Téoros Review, 33, 2.

Tijana, R, (2007). World Heritage: Issues and debates, Journal of Tourism, Vol. 55 No 2, P 209.

*** CSAM, (1995). The Conservation of Archaeological Sites in the Mediterranean region, international conference organized by IE Getty Conservation Institute and Ie J. Paul Getty Museum, from 6 to 12 May 1995, P13.

*** DTA . (2015). Tourism and Handicrafts Directorate. BATNA province, Algeria.

*** European Commission (2004). Development of archaeological sites in urban areas, Directorate general of Research, Belgium. P24.

*** Executive Decree 07-86, (2007). Laying down the procedures for the establishment of the plan of tourist development of the areas of expansions and tourist sites, Algeria, in Official Journal of the Algerian Republic, $\mathrm{n}^{\circ} 17$.

*** Executive Decree $\mathrm{n}^{\circ}$ 10-131, (2010). Bearing delimitation, Declaration and classification of expansion areas and touristic sites. Algeria, in Official Journal of the Algerian Republic, $\mathrm{n}^{\circ} 30$

*** Executive Decree No. 03-323, (2003). Concerning the modalities for the establishment of the plan for the protection and enhancement of archaeological sites and their zone of protection (PPMVSA), Algeria. in Official Journal of the Algerian Republic, $\mathrm{n}^{\circ} 60$.

*** Executive Decree No. 98-70, (1998). The establishment of the National Agency for the tourism development and laying down its statutes, in Official Journal of the Algerian Republic, $\mathrm{n}^{\circ} 11$.

*** Law, 98-04. (1998). Related to the protection of the cultural heritage, Algeria, Official Journal of the Algerian Republic, $\mathrm{n}^{\circ} 44$.

*** Monograph (2017). Commune of Timgad, Batna, Algeria.

*** Order, $\mathrm{n}^{\circ} 73-38$. (1973). On Ratification of the Convention concerning the protection of the World Cultural and Natural Heritage, in Official Journal of the Algerian Republic, $\mathrm{n}^{\circ} 69$.

** PAT. (2015). Plan of Touristic Development in the Area of expansion and touristic site ZEST Timgad, Tourism and Handicrafts Directorate. BATNA province, Algeria.

*** PDAU. (2012). Urban planning and development master plan of Timgad commune, Algeria.

*** SDZAH. (2007). The Master Scheme of archaeological and historical areas , Ministry of Culture, Algeria, P113.

*** SEBAHI S. (2016). Property Algeriens inscribed on the world heritage list, P1,2.

** SNAT. (2010). National Scheme for the Territory planning, ministry of the Territory planning of the Environment and the city, Algeria. P14.

*** Timgad Archaeological Department. (2016 ). BATNA province, Algeria.

*** UNESCO. (2013). Tourists and inhabitants in the World Heritage Sites, acts of the 4th day: The Chair "Culture, Tourism, Development "The IREST and the EIREST, University of Paris 1 Panthéon-Sorbonne 22 October 2013.P7, 8.

Submitted:

02.10.2019
Revised:

26.02.2020
Accepted and published online 03.03 .2020 